\title{
The Use of First Language (L1) in EFL Classrooms: Teachers' Practices and Perspectives
}

\author{
Hanna Sundari, Rina Husnaini Febriyanti \\ Faculty of Language and Arts, Universitas Indraprasta PGRI Jakarta, Indonesia
}

Hanna.sundari@gmail.com/hanna.sundari@unindra.ac.id

First draft received: 30 Oct 2020 Date Accepted: 21 Jan 2021 Final proof received: 5 Apr 2021

\begin{abstract}
Teaching English in the context of foreign language needs vigorous efforts and strong commitment, especially for non-native English-speaking teachers to maintain professionalism and to achieve the success of learning language. Generally, it is believed that a teacher should be a language model for the learners by providing a great deal of input in the target language and applying the L2 only policy. However, some teachers finally decide to use their first language (L1) or mix it with the target language (L2) while teaching. This qualitative study investigated the frequencies, functions, and teachers' perceptions of their L1 use in EFL classes. Twenty English teachers from lower secondary schools in Jakarta, Indonesia were asked to participate. The data were collected through classroom observations, in-depth interviews, and focus group discussions. The finding obtained that the frequency of the L1 was seemingly noticeable but not overused. Moreover, teachers used first language mostly for activity objective, translation, comprehension check, and activity instruction. The finding also revealed that the majority of the teachers decided to mix first language and target language with different proportions. Meanwhile, the others decided to use a small portion of target language. Only few teachers consistently tried to instruct mostly in target language. The finding implies the need for teachers to enhance the usage of first language (L1) during the teaching process to get maximal result.
\end{abstract}

Keywords: EFL; first language; non-English speaking teachers

To cite this paper (in APA style):

Sundari, H., \& Febriyanti, R. H. (2021). The use of first language (L1) in EFL classrooms: Teachers' practices and perspectives. International Journal of Education, 14(1), 70-77. doi: 10.17509/ije.v14i1.26375

\section{INTRODUCTION}

In the world of second/foreign language (L2) teaching and learning, the use of first language or home language (L1) by both teacher and student in the L2 classroom has been a controversial issue among language experts and practitioner-teachers (Almoayidi, 2018; Balabakgil \& Mede, 2016; Bozorgian \& Fallahpour, 2015; Campa \& Hossein, 2009; Galali \& Cinkara, 2017; Yavuz, 2012). Some of them believe in the policy of L2 only (English, in this case) underpinned by several argument (Auerbach, 1993; Cook, 2008). On the other side, some evidences show that using L1 in L2 classroom is still considered beneficial and needed to facilitate language learning and teaching (Auerbach, 1993; Cook, 2008; Macaro, 2009)

At first, in the era of Grammar-translation method, language was taught by translating techniques and the use of L1 to teach L2 was universal and acceptable as a norm (Hashemi \& Sabet, 2013; Yavuz, 2012). Later, in the line with the criticism of GTM in the twentieth century, the student's first language was nearly avoided; from Direct Method to Audio-lingual Method to Task-bask Learning, it has been argued that the less L1 is used in the class, the better the teaching (Cook, 2008). Moreover, Philipson has emphasized that English is best taught monolingually; the more English, the better the result (Auerbach, 1993). Berlitz, from Berlitz' Direct Method, even directly ask the teachers to use L2 only in language classroom (Hariri, 2015). The monolingual approach of L2 teaching also gains support from Krashen (1981) with his Theory of Second Language Acquisition (SLA) which is stated that the L2 learning follows the same route as acquiring the mother tongue so that the L1 in learning language should be avoided (Alshehri, 2017). The use of L1 can be a hindrance in second language acquisition.

Despite the views of the policy of L2 only in language classrooms, some recently different arguments come to light in discussion on the benefits and frequency of L1 in L2 classroom. Campa \& Hossein (2009) wrote that the usage of L1 brings cognitive and sociolinguistic positions for the students 
in the language classroom. Correspondingly, Cook (2008) explained that the L1 is used by teachers in some ways, such as explaining grammar, tasks, and exercises to the students and they naturally use it their classroom activities. In addition, some research also provides the evidence on how L1 helps L2 to learn and to teach. The study by Bozorgian and Fallahpour (2015) who investigated 155 university students in a pre-intermediate 12-week EFL course in Iran showed that the small amount of L1 in the classroom is as a facilitative tool in order to achieve a wide range of teaching learning purposes: to convey meaning, manage classroom, make friendly environment, reduce students' anxiety, facilitate communication, and elaborate the course objectives. In 2017, Alshehri (2017) surveyed 104 female teachers from different nationalities (Saudis, South Asian, Arabic, others) to find out their attitudes toward and frequency of L1 in their EFL classrooms. He then concluded that the teachers use L1 for some functions, such as explaining grammar and developing rapport with the students; meanwhile, the students use it mainly for translating new vocabulary and preparing tasks.

Furthermore, Macaro (2009) summed up that the usage of first language facilitates learning and recalling second-language vocabulary and effects to the first language in reading. The research results from Iraqi tertiary level students also revealed the positive attitude toward the L1 in facilitating target language learning (Galali \& Cinkara, 2017). Then Hongkong teacher thought that the usage of L1 is permittable to maintain students' interests and involvement (Carless, 2007). Particularly the use of L1 as a source of humor, the study by Jawhar (2018) has proved that it has obviously increased the students' interactional competence. Within the study on EFL senior high schools in China, Li (2018) reported that, in the form-focused IRF cycle, L1 can function as linguistic clues to scaffold students' learning; at the same time, the students can benefit from L1 in teacher's instruction so as to keep in touch with the teacher and concentrate on pedagogical goals. Not only that, the research by Paker \& Karaağaç (2015) showed that the language instructors use L1 mostly for building rapport, making topic/meaning clear, and explaining difficult concepts/ideas.

Regarding the use of L1 for teaching EFL in the Indonesian context, Manara (2007) investigated 9 Non-native English teachers from three universities in Central Java, Indonesia to determine the perceptions and purposes of the use of L1 in their classrooms. She concluded that both teachers and students agreed that English praxis should be used to the fullest although the teacher also thought that the essential considerations in using L1 support, such as the course's goal, students' level of proficiency, and the immediacy of responses. In 2012, Hidayati (2012) also reported her study of the role of L1 (Bahasa Indonesia) in teaching receptive skills and grammar in EFL classes in university level. After conducting observation and interviewing three participant teachers and surveying 100 students through questionnaire, it can be concluded that Bahasa Indonesia is helpful only when it is used judiciously, and it functions to explain grammar and difficult vocabulary items, to check students' comprehension, to make jokes, to give suggestions, and to give complex classroom instruction. At the level of classroom practices and interaction in EFL classrooms, the teachers and students who share the same L1 tend to use it for many purposes and different frequencies. And it evidently facilitates language learning in the classroom when it's used proportionally. As Yavuz (2012) concluded about the use of L1, it can neither be ignored nor overused in language classrooms. In addition, Pan and Pan (2017) also pointed out that the use of L1 is justified, but none of the its supporters endorses unlimited use.

Despite the fact that the research on the issue of L1 use in language classrooms has been widely and extensively conducted, most of them explored the perception, frequency, and purposes in the university level. Meanwhile, its exploration on the different settings (primary or secondary levels) is still uncovered and needed to figure out the differences (Almoayidi, 2018; Manara, 2007). Therefore, the current study has attempted to address to the following questions: 1) How frequent is the L1 used by the teachers in the EFL classroom? 2) What are the functions/purposes of its use? and 3) How do the teachers perceive their L1 use in EFL secondary classes?

\section{METHOD}

To answer the research questions, the study was carried out in descriptive, qualitative approach. The participants were twenty non-native English teachers whose teaching experiences ranged from four to thirtyseven years from eight lower secondary schools (SMP) in Jakarta, Indonesia. They taught grade 7 (25\% of participants), grade $8(20 \%)$ and grade 9 (55\%).

To collect the data, the instruments were classroom observation/recordings, in-depth interviews, and focus-group discussion (FGD). The classroom observation/recordings were conducted for those were willing for classroom observation. Six of all teacherparticipants provided their consents with the total of 5.8-hour recordings to figure out the frequency and the functions/purposes of the usage of L1. The recordings were captured by camera that was placed in the back or the front of the class. The class recordings were then listened, analyzed, and coded from the teachers' utterances based on two aspects: frequency and function/purpose. The utterance cuts were determined by the shift among them. And the classification of the utterances was based on the teacher's talk analysis by Duff and Polio (1990)'s category of utterances. Meanwhile, the utterances that contain the use of L1 were then tallied and classified based on the coding schemes of the functions/purposes suggested by Campa and Hossein, (2009). Observation sheets were 
also written to collect what the researcher's see and capture on the classroom atmosphere especially on the students' responses on the use of L1 that were probably not captured on camera.

Not only class recordings to 12 interviews of eleven teacher-participants but also 2 FGDs of nine teacher-participants were conducted to elicit the teachers' perspectives about frequencies and purposes on the use of L1 in their EFL classrooms as a triangulation of the gathered data from class recordings. Both interviews and FGD were videorecorded and transcribed in verbatim helped by NVivo version 8. Furthermore, member-checking technique by the second author was also applied to verify the gathered data valid and reliable.

\section{RESULTS AND DISCUSSION}

After collecting and analyzing data, the gathered data resulted in the frequency and the functions of the utterances spoken by the teacher participants who were teaching English in their class as well as the reasons and perspectives of the use of L1. Those data are presented based on the research question formulation, as follow:

\section{The Frequency of the Use of L1}

From classroom recordings, the collected data showed that the entire utterances expressed by the teacher participants reached 1300 times of occurrences in total. With $54 \%$ of the total utterances, the use of L2/target language, which is completely in English, seems dominating the language classroom spoken by the teachers. However, the number of L2 occurrences were less than in the study by Campa and Hossein (2009) in which L2 word yielded $88.2 \%$ of total words. In addition, the data also showed that the utterances of English with one word/phrase in Bahasa Indonesia was occurred 131 times, equals $10 \%$ of all utterances. Meanwhile, the mixed utterances, that are approximately an equal mixture of English and Bahasa Indonesia spoken by the teacher participants, gained 76 times of occurrences. From these L2 occurrences, it can be drawn a pre-conclusion that the English in EFL classroom is mostly and predominantly used by the teacher.

\section{Figure 1}

The Frequency of Utterances

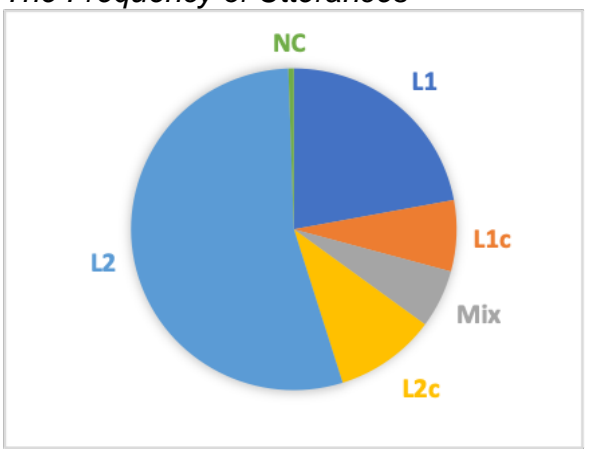

Despite the fact that English becomes the primary language spoken by the teachers in EFL classroom, the number of occurrences of L1 (Bahasa Indonesia) cannot be neglected and ignored (see Fig. 1). Based on the class recordings, teacher participants spoke completely in Bahasa Indonesia for 287 times and used it with one word/phrase in English for 93 times. Those occurrences equal $29 \%$ of total utterances expressed by the teacher. The percentage of the use of Bahasa Indonesia becomes 35\% of all utterances if the mixture of English and Bahasa Indonesia is included. This is much higher than what was found by Campa and Hossein (2009) with only $11 \%$ of the use L1 word. However, almost similar result can be found on the study by Hidayati (2012) which the use of L1 reached $30 \%$ to $49 \%$ among six teachers recruited.

\section{The Functions of the Use of L1}

Table I shows the functions or purposes of use of L1 (Bahasa Indonesia) uttered by the teacher participants from class recordings. At first, the fourteen categories were selected to code the utterances as proposed by Campa and Hossein (2009). In fact, some utterances occurred in the data could not be coded based on the selected categorization. As a result, those were noted as no code or NC because it was uttered in Arabic language.

Table 1.

The functions of $L 1$ utterances

\begin{tabular}{c|r|r|r|r|r|r|r|r|r|r|r|r|r|r|r|r|r|}
\hline $\mathbf{V}$ & $\mathbf{1}$ & $\mathbf{2}$ & 3 & $\mathbf{4}$ & $\mathbf{5}$ & 6 & $\mathbf{7}$ & $\mathbf{8}$ & $\mathbf{9}$ & $\mathbf{1 0}$ & $\mathbf{1 1}$ & $\mathbf{1 2}$ & $\mathbf{1 3}$ & $\mathbf{1 4}$ & $\mathbf{1 4}$ & $\mathbf{K C}$ & Total \\
\hline 1 & $\mathbf{1 1}$ & $\mathbf{0}$ & 0 & 7 & 7 & 1 & 0 & 7 & 2 & 2 & 0 & 0 & 0 & 3 & 0 & 7 & 47 \\
\hline 2 & 1 & 3 & 3 & 2 & 0 & 0 & 1 & 2 & 0 & 0 & 0 & 0 & 0 & 5 & 3 & 9 & 29 \\
\hline 3 & 1 & 6 & 6 & 4 & 0 & 0 & 4 & 2 & 1 & 0 & 0 & 0 & 0 & 2 & 0 & 4 & 30 \\
\hline 4 & 35 & 0 & 1 & 20 & 16 & 1 & 10 & 25 & 1 & 10 & 1 & 2 & 3 & 8 & 6 & 18 & 157 \\
\hline 5 & 4 & 0 & 5 & 13 & 4 & 3 & 0 & 4 & 1 & 0 & 0 & 0 & 2 & 1 & 3 & 4 & 44 \\
\hline 6 & 15 & 0 & 18 & 27 & 48 & 18 & 6 & 29 & 10 & 0 & 3 & 0 & 4 & 2 & 2 & 19 & 201 \\
\hline 7 & 14 & 0 & 2 & 5 & 11 & 3 & 8 & 10 & 0 & 1 & 0 & 5 & 3 & 2 & 2 & 15 & 81 \\
\hline Total & 81 & 9 & 35 & 78 & 86 & 26 & 29 & 79 & 15 & 13 & 4 & 7 & 12 & 23 & 16 & 76 & 589 \\
\hline
\end{tabular}

From the table above, Activity Objective (5) is the most frequently used function. This indicates that the goal/aim of the lesson, the objective of activity/task, and the topic/material discussed are better and more understandable when using Bahasa Indonesia. The L1 is more preferable to express the complex expressions such as:

"karena lamanya pake for, for 2 hours, selama dua jam. Untuk menyatakan lamanya. Atau tanya mengenai lamanya nya pakai long." (WC1).

(because of its duration, use for, for 2 hours. To say duration. Else, when asking duration, use long) "keunggulan-keunggulan taman menurut lima siswa yang berdiskusi. Eh 6 siswa yang berdiskusi" (WC5)

(the advantages of parks based on 5 students on the discussion. Ups, 6 students.) (WC5). 
"Karena kalo kita menanam kan harus ditutup akarnya." (WC6)

(because when planting, we should cover the roots, right)

The functions of L1 to explain grammar or difficult concepts and conveying meaning were also widely found in many research (Balabakgil \& Mede, 2016; Cook, 2008; Hidayati, 2012; Paker \& Karaağaç, 2015). At this stance phase, it can be concluded that the teachers use the L1 to consolidate students' knowledge about L2, for example its vocabulary, sentence structure, and cultural aspects (Pan \& Pan, 2017).

Furthermore, the function of translation (1), comprehension check (8) and activity instruction (4) reach the next three highest occurrences with 81, 79 and 78 times of occurrences in respectively. This means that the teacher participants prefer to use Bahasa Indonesia to check the students' understanding of the materials and to deliver the steps and how the students to do the tasks in the classroom; as also found in the study by Hashemi \& Sabet (2013) in which concluded that the main areas of L1 use are in explaining grammatical terms, introducing abstracts words and checking students' comprehension. And then, to make meaning of difficult concepts/ideas easier, the teacher participants choose translation. The excerpts from class recordings are below.

"You said you understand. What do you have to do? Di suruh ngapain?” (WC3)

"Listen. Koq ini advise? Bukannya pakai -c? ya ok, sorry, bro. Koq gak pake -c sih? What do you advise me? Ini verb atau noun? Verb atau noun? Verb." (WC7)

(Listen. Why is it advise? Why don't use -c? ok, sorry. Why not use -c? what do you advise me? Is it verb or noun? Verb or noun? verb)

"Dengan memilih satu yang ada di sini" (WC1)

(by choosing one of these)

The function of L1 as translation was also revealed in the study by Campa and Hossein (Campa \& Hossein, 2009), Bozorgian and Fallahpur (Bozorgian \& Fallahpour, 2015) and Paker and Karaagac (Paker \& Karaağaç, 2015). Meanwhile, the use of L1 allows the students to complete the task more easily because the teachers explain it in students' first language. Therefore, L1 helps the students in defining unknown words directly and do the task easily, as stated by Pan and Pan (Pan \& Pan, 2017).

The other functions of L1 in EFL classroom that occurred from the data are evaluation (3), personal comment (7) and elicitation of student contribution which gained 35,29 , and 26 times in respectively. The examples can be seen on the excerpt below:

"Jangan komplain ya. Jangan komplain this song because" (WC7)

(No complaint, please. No complaint.)

"Salah. Koq" (WC5)

(It's wrong.)

"Buat apa? Emang pengen dapat 10?" (WC2) (for what? Do you want to get 10?)

"Ayo yang cepat ngerjain siapa?" (WC6)

(Come on, who does the fastest?)

Even though teacher participants tend to give positive evaluation such as good, very good in English or target language, some evaluations are uttered in L1, particularly when giving negative evaluation and correction in the students' mistakes and misbehaviour. On the other hand, study by Campa and Hossein (2009) revealed the functions of personal comment in L1 words as the second most frequent functions on their data. Personal comments are as a contribution of personal note on the teaching. Beside the function of personal comments, using L1 to make jokes (humour 13) was also found 12 times of occurrences from the data. The similar finding can be found on Jawhar (2018)'s study on investigation of teaching English towards university students in Saudi. Humours in L1 was also occurred in research by Hidayati (2012); the teachers prefer L1 to make jokes since the students often feel difficult to make meaning of amusement when using the target language (Hidayati, 2012). Meanwhile, the study by Paker \& Karaağaç (2015) shows that making jokes and personal comments to show concerns and empathy in L1 words aims at building rapport to the students.

The data of the teachers' utterances, it shows that the teacher participants have their roles as bilingual instructors (14a) who speak arbitrarily between L1 and L1 with 23 times of occurrences, for example, "so sometimes, we don't know exactly. Ada pepatah atau sebuah such a wise word say ..."(WC4). Moreover, they sometimes utter the word or term from the L1 culture (14b) with the occurrences of 16 times, such as "If asking your friend, you got the answer, but your listening still payah, you know?" (WC2). This indicates that the code-mixing between L1 and L2 is occasionally applied when the teachers and students share the same L1.

The other functions in the use of L1 in EFL classroom found from the data were classroom equipment, administrative issues, L1-L2 contrast, reaction to the student's questions, and repetition of student's L1 utterances; with the occurrences 15, 13, 9,7 , and 4 times in respectively. It can be stated that the L1 utterances were used for discussing course policies, attendance, and other administrative issues, and conflict management (Paker \& Karaağaç, 2015). The functions of L1 use from the teacher-participants' utterances on this current research are equivalent to what Franklin found that more than $80 \%$ of teachers used L1 to explain grammar and discuss objectives; more than $50 \%$ to evaluate written work and teach background; but less than $16 \%$ to organize classroom activity and to informal chat (Cook, 2008).

Besides those functions of L1 utterances, at least 76 times occurrences of L1 uttered by the teacherparticipants cannot seemingly be categorized. They frequently use several particles in Bahasa Indonesia, such as ya, nah, kan, loh, yuk in classroom language. 
These particles are used either in initial or final position of the utterances, for example "So that, later on, you will get used to people talking like me. Ya" (WC2) and "Nah. If you were as Merly and Jennifer" (WC7). And then the functions are probably to get student's attention, to emphasize the explained concepts, and to show surprise. The teachers may think that they couldn't find the similar expressions in L2 as well as these particles are very common in L1 daily conversation. Accordingly, their uses in EFL classroom sound reasonable and natural.

From the 76 times of L1 occurrences as no code category, the utterances that show to give advice or suggestions from the teachers to the students are also frequently found. For example, one teacher participant says "Makanya, jangan ingkar janji." (therefore, don't break your promise) (WC6). Giving suggestion/advice or evaluation of the students' behaviour in the classroom shows that the teachers have the role as the classroom manager and evaluator. It might indicate that the social relation between student and teachers is as children-parent relationship or lesscompetent learners-more experienced teacher which the gap of age and competences are widely opened between them. As a result, the teacher might have authority to evaluate students' proficiency and behaviour in the class; at the same time, they also might think that it is part of job to be teacher-educator to maintain discipline and build positive behaviour. Meanwhile, their preference to use L1 in expressing suggestion/advice is to make the students understand what they are saying directly and easily. At this point, it can be summed up that the functions of Bahasa Indonesia in EFL classroom are mostly to give activity instruction, to translate difficult word, to check students' comprehension as well as to give feedback and to maintain discipline, as also already mentioned by Cook (2008).

\section{Teachers' Perspectives on the Use of L1}

This section presents the perspectives from the teacher participants about their uses of L1 in the classroom particularly the purposes and the reasons grounded their practices. The data were mostly gathered from in-depth interview and focused-group discussions completed by observation sheets.

From the interview and FGD of the teacher participants, the majority of the participants stated that the medium of instruction in their EFL classrooms uses the mixture of L1 and L2 with the slightly different proportions. For example, one teacher participant said that "iya, tidak hanya full English sih, Cuma dimixlah antara Bahasa Indonesia dan bahasa Inggris" (yes, it is not full English. It is mixed between Bahasa Indonesia and English) (TW-07). The similar result was also found on the study by Petek (2013) which revealed the use of both L1 and L2 as medium of instruction in foreign language classroom. In addition, Hariri (2015)'s research shows that $72 \%$ of teachers who live and study in Arabic-speaking countries participating on the survey claimed that they use L1 in and outside the classroom.

Moreover, the small number of the teacher participants declared that L2 is dominantly used for classroom language and they try to avoid translation technique as a tool. On the contrary, the other small number of them expressed that Bahasa Indonesia is mostly spoken in the classroom with approximately $70 \%$ of total utterances, as the excerpt below:

“... maka saya coba sekali-sekali itu menggunakan Bahasa Inggris. Dan mereka enggak ngerti gitu, tidak paham. Jadi saya $\square$ iker daripada nanti materinya tidak sampai kepada siswa, jadi saya campur bahasanya. Presentasenya antara 70 banding 30 ... 70\% Bahasa anak dan 30\% Bahasa target".

(so sometimes I try to use English. However, they don't understand. Therefore, I think I mix the languages instead of missing of the materials/lessons. The percentages are $70 \%$ and $30 \% \ldots 70 \%$ for student's first language and $30 \%$ for target language) (TW-07).

In addition to the frequency of L1 use in the EFL classrooms, the teacher participants were then asked when and for what situation they use L1 during teaching. The excerpts from the interview said:

"nanti kalo di inti, baru itu kita masuk ke Bahasa Indonesia-nya. Jadi separuh menggunakan Bahasa Inggris lalu kita jelaskan dalam Bahasa Indonesia."

(when the main activity, we use Bahasa Indonesia. So, for half of the teaching session, teacher uses English; and then Bahasa Indonesia is used for the other half of session) (TW-11).

"Bahasa Indonesia dipakai untuk menerangkan materi bahasan yang sulit."

(Bahasa Indonesia is used for explaining difficult topics) (CW-11).

“... sedikit Bahasa Indonesia, terutama untuk penegasan/penguatan disiplin."

(... just a small use of Bahasa Indonesia, primarily for strengthening of discipline) (LO05).

“...sementara bahasa Indonesia digunakan untuk memberikan komentar, instruksi yang panjang dan rumit, merespon pertanyaan siswa, dan penjelasan lainnya."

(... while Bahasa Indonesia is used for giving comments, long difficult instructions, responding student's questions, and delivering other explanation) (CO-08)

The data shows that the teacher participants prefer L1 to L2 in classroom to explain difficult concepts/topics during main activity of the lesson, give comments and instructions, and feedbacks, and discipline student related to classroom behavior and 
equipment. These findings are consistent with what Harmer said that the classes with low level learners, the L1 is used to explain topics/materials, discuss lessons, and deliver announcements that are probably difficult to understand when using L2 (Harmer, 2005). To be more specific on classroom discipline, the similar finding can be seen on the study by Yavuz (2012) which resulted in the data that teachers get forced to use L1 to control students' behaviors when the classes are crowded and noise.

Concerning to the considerations in using L1 for language classroom, the teacher participants stated some reasons for their preferences. These excerpts below cover the information.

\begin{abstract}
"kelas dengan kemampuan bahasa Inggris rendah sekali menggunakan bahasa Indonesia, kecuali untuk kalimat perintah."

(for the class with a very low English Level of proficiency, Bahasa Indonesia is applied, except for commands) (CW-4).

"saya lebih supaya mereka tidak frustrated belajar bahasa Inggris, jadi kadang-kadang saya selipi bahasa Indonesia."

(for me, it is more to not make the students frustrating when learning English. Therefore, I sometimes combine with Bahasa Indonesia) (TW-02).

“... mengajar menggunakan full English tapi disini karena saya juga mengajar di beberapa level tingkatan yang siswanya rata-rata menengah ke bawah.."

(teaching uses full English, but here because I have also taught in several levels of the students' language level that are partially in low levels) (TW-07).
\end{abstract}

The use of L1 preferred by the teacher participants are based on some considerations. At first, student's proficiency level of English is the first aspect to consider. When entering the class with relatively low level of English learners, the L1 or students' first language is mostly used for classroom language; the higher the learners' level of L2 the more frequently the use of $L 2$. Meanwhile the $L 2$ as communicative language spoken by the teachers is slightly limited for only some expressions. The similar factor was also found on the research by Campa and Hossein (2009) in which student' level determines how much L1 use in the classroom. In addition, this finding supports the view of Brown who wrote that for beginner level learners, the main objective in learning language is to understand and to produce spontaneous language but it is still in the practices of controlled repertoire of language (Brown, 2007). As also the conclusion on Pan and Pan's research, the quantity of L1 use depends on the students' proficiency levels and teaching purposes in which L1 may be spoken from beginner to lower-intermediate levels on a gradually decreasing scale (Pan \& Pan, 2017).
Related to the teacher's proficiency in L2, only one of the teacher participants stated that "for me it doesn't matter; mungkin ada beberapa guru yang capek dia ngomong bahasa Inggris terus [maybe some teacher feel tired speaking in English]... or they don't know how to say English and they make it with Bahasa." (TW-02). Meanwhile, most of the teacher participants do not consider it as a factor in using L1/L2. This finding may support what was stated by Duff and Polio. They wrote that the role of teachers' English proficiency as a factor influencing the amount of L2 use in classes can be discounted; in the other words, oral proficiency does not determine to push teachers to speak more or less of the L2 (Duff \& Polio, 1990).

The second consideration in using the L1 in EFL classes is social/affective factor. When teachers use L2 words that the students do not fully understand. Consequently, they fail to make meanings of the information, communication and instructions given by the teachers. As a consequence, they feel confused, frustrated, and lost in learning L2. The feelings of failure may demotivate them. Therefore, the teachers think that they need to place themselves and the languages used in the classroom suit to the students' language levels. The study by L1 on application of L1 in China brought the similar view that when students hear L1 from their teachers and they allow to use it, they become more confident and willing to participate in language discourse. In the other words, L1 can create harmonious situation to encourage students' participation in the classroom (Li, 2018).

\section{CONCLUSION}

This research is aimed at describing the use of L1 in EFL classes, particularly in the aspects of frequency, functions, and reasons from teachers' practices and perspectives in lower secondary schools. After analyzing and presenting the gathered data, it can be drawn some summaries. Firstly, from the 1300 times of total teacher's utterances, the utterances completely in L1 were 287 times of occurrences, equal to $29 \%$. The percentage rose to $35 \%$ when the L1 utterances were combined with one word/phrase in L2. This number of L1 utterances can be said to be neither significant nor overuse of L1, considering that the students in the research context were from lower secondary school and could be categorized as beginner-level learners. The second conclusion is that the L1 used by the teachers was mostly for activity objective, translation, comprehension check, activity instruction, evaluation, personal comments, eliciting contribution, and humors. In other words, the teachers preferred using first language to target language to explain difficult concepts/topics/materials, to check how well students understand the lesson and to deliver how to do the tasks in the class. Moreover, the L1 was also more preferable to give personal comments and humors as well as to evaluate students' performance and to maintain student discipline during the lesson. It can be assumed that 
the teachers chose to speak in first language to students in the classroom in the level of classroom management, i.e., lesson delivery, comprehension check, and student discipline.

From the teachers' perspectives, it can be summed up that majority of the teachers chose to mix L1 and L2 for language used in the classroom. Meanwhile, the small number of them decided to use either L1 or L2 dominance with some considerations. Students' L2 proficiency of English is the first factor to consider. When teaching students with low level of English, the students' first language (L1) is more preferable. In addition, to avoid students' confusion, frustration and demotivation in learning English, teachers finally resort to speak in L1 because those social/affective factors may hinder the learning process. Implications for this study is to enhance the use of L1 in order to improve students' input from the teachers as the role model of target language. Recommendation for further research may analyze about the factors of L1 use from both teacher and students' viewpoints in the perspectives of psycholinguistics and/or sociolinguistics.

\section{REFERENCES}

Almoayidi, K. A. (2018). The effectiveness of using L1 in second language classrooms: A controversial issue. Theory and Practice in Language Studies, 8(4), 375. https://doi.org/10.17507/tpls.0804.02

Alshehri, E. (2017). Using learners' first language in EFL classrooms. IAFOR Journal of Language Learning, 3(1), 20-33. https://doi.org/10.22492/ijll.3.1.02

Auerbach, E. R. (1993). Reexamining English only in the ESL classroom. TESOL Quarterly, 27(1), 932.

Balabakgil, B., \& Mede, E. (2016). The use of L1 as a teaching strategy by native and non-native EFL instructors at a language preparatory program in Turkey. Advances in Language and Literary Studies, $\quad 7(6)$, 15-35. https://doi.org/10.7575/aiac.alls.v.7n.6p.15

Bozorgian, H., \& Fallahpour, S. (2015). Language teaching research teachers ' and students ' amount and purpose of L1 use: English as foreign language ( EFL) classrooms in Iran. Iranian Journal of Language Teaching Research, 3(July), 67-81.

Brown, H. D. (2007). Teaching by principles: An interactive approach to language pedagogy (second ed.). Pearson Education.

Campa, J. C. de la, \& Hossein, N. (2009). The Amount, purpose, and reasons for using $L 1$ in L2 classrooms. Foreign Language Annals, 42(4), 742-759.

Carless, D. (2007). Student use of the mother tongue in the task-based classroom. ELT Journal Advance Access, 6(2007), 1-8. https://doi.org/10.1093/elt/ccm090

Cook, V. (2008). Second language learning and language teaching (fourth ed.). Hodder
Education

Duff, P. A., \& Polio, C. G. (1990). How much foreign language is there in the foreign language classroom? The Modern Language Journal, 74(2), 154-166.

Galali, A., \& Cinkara, E. (2017). The use of L1 in English as a foreign language classes: insights from Iraqi tertiary level students. Advances in Language and Literary Studies, 8(5), 54. https://doi.org/10.7575/aiac.alls.v.8n.5p.54

Hariri, K. Al. (2015). Using L1 in teaching English to advanced students. International Journal of Applied Linguistics and English Literature, 4(6), 4-7. https://doi.org/10.7575/aiac.ijalel.v.4n.6p.220

Harmer, J. (2005). The practice of english language learning. Pearson Education Limited.

Hashemi, S. M., \& Sabet, M. K. (2013). The Iranian EFL students' and teachers' perception of Using Persian in general English classes. International Journal of Applied Linguistics \& English Literature, 2(2), 142-152. https://doi.org/10.7575/aiac.ijalel.v.2n.2p.142

Hidayati, I. N. (2012). Evaluating the role of L1 in teaching receptive skills and grammar in EFL classes. Indonesian Journal of Applied Linguistics, $1(2), \quad 17$. https://doi.org/10.17509/ijal.v1i2.82

Jawhar, S. S. (2018). The use of L1 as a source of humour to facilitate interaction in EFL classrooms. Arab World English Journal, 9(3), 294-310. https://doi.org/10.24093/awej/vol9no3.20

Li, J. (2018). L1 in the IRF cycle: a case study of Chinese EFL classrooms. Asian-Pacific Journal of Second and Foreign Language Education, 3(1), 1-15. https://doi.org/10.1186/s40862-0170042-y

Macaro, E. (2009). Teacher use of codeswitching in the second language classroom: Exploring 'optimal'use. In First Language Use in Second and Foreign Language Learning. Second Language Acquisition Series. (pp. 35-49).

Manara, C. (2007). The use of L1 support: Teachers' and students' opinions and practices in an indonesian context the use of L1 support: Teachers' and students' opinions and practices in an Indonesian Context. The Journal of Asia TEFL, 4(1), 145-178.

Paker, T., \& Karaağaç, Ö. (2015). The use and functions of mother tongue in EFL classes. Procedia - Social and Behavioral Sciences, 199, 111-119. https://doi.org/10.1016/j.sbspro.2015.07.494

Pan, Y., \& Pan, Y. (2017). The use of L1 in the foreign language classroom. Colombian Applied $\begin{array}{ll}\text { Linguistics Journal, } & 12(2),\end{array}$ https://doi.org/10.14483/22487085.85

Petek, E. (2013). Teacher's beliefs about classroom interaction and their actual practices: A qualitative case study of a native and a non- 
native English teacher's in-class applications. Procedia - Social and Behavioral Sciences, 70, 1195-1199.

https://doi.org/10.1016/j.sbspro.2013.01.176

Yavuz, F. (2012). The attitudes of English teachers about the use of L1 in the teaching of L2. Procedia - Social and Behavioral Sciences, 46, 4339-4344.

https://doi.org/10.1016/j.sbspro.2012.06.251 